\title{
THE IMPACT OF EFFLUENT PRODUCED FROM NTAK INYANG AND IBA OKU SLAUGHTERHOUSES ENVIRONMENT
}

E. C. UKPONG

(Received 16, September 2011; Revision Accepted 30, May 2012)

\begin{abstract}
The characteristics of effluent produced in Uyo Capital city slaughterhouses located at Ntak Inyang and Iba Oku were monitored by water and wastewater parameters. The wastewater from the slaughterhouses generally shows a high pollutant strength. The BOD value of $7.25 \mathrm{mg} / \mathrm{l}$, DO value of $0.21 \mathrm{mg} / \mathrm{l}$, nutrient values of 1.14 and $1.25 \mathrm{mg} / \mathrm{l}$, respectively. The heavy metals concentrations recorded are $0.05,15.5,16.05,0.75$ and $0.10 \mathrm{mg} / \mathrm{l}$ for cadmium, zinc, copper, iron and lead with several million colony forming units (CFU) $100 \mathrm{ml}$ of total coliform and other bacteria. The presence of pathogens such as E.coli and others were also present. Effluents from the abattoir sites were found not to increase the $\mathrm{BOD}, \mathrm{NO}^{3-}, \mathrm{PO}_{4}^{3-}, \mathrm{Cd}, \mathrm{Fe}, \mathrm{Pb}, \mathrm{Cu}$ and $\mathrm{Zn}$ values of the surface water. These values were lower than the WHO/FMENV limits, due to dilution from the heavy down pours during sampling. The present of microbial populations in the surface water indicate the risk of human infections in the study area.
\end{abstract}

KEYWORDS: Slaughterhouse effluent, heavy metals, wastewater, pollution, bacteria and total coliform.

\section{INTRODUCTION}

Slaughterhouses are needed primarily to serve the large-scale demand for meat in urban areas where there's no livestock. Thus, the slaughterhouses have developed as an adjunct of the city. However, in spite of the public and international agencies policy focused on this problem, the situation in Uyo Capital City seems degenerating and therefore demands greater attention. These degenerating activities at the slaughterhouses have greatly increased the volume of effluents and animals waste released into the environment with negative socioeconomic and health implications.

These waste products and effluent from abattoir and subsistence consumption are often so thinly spread through the environment that the absorptive capacity of the natural resources is hardly reached. However, with increasing income in Uyo, an increasing proportion of animals and animal product go through market and processing channels before consumption. This places an increased level of pressure on the agricultural sector-cum-environment. The standard and regulations governing slaughterhouses vary considerably around the world. In many countries, the slaughter of animals is virtually unregulated by law. Often, however, it is strongly regulated by custom and tradition. In the non-Western world including the Arab world, the Indian sub-continent, both forms of meat are available: one which is produced hygienically in modern mechanized slaughterhouses, and the other of the animals, slaughtered (conscious) in local butcher shops. However, as the expected increase in demand referred to above is to be met, it is likely that negative effects of livestock production and meat processing will continue to emerge.

Apart from the negative impact of effluent or animal waste discharge on biodiversity, there are a number of human health hazards involved. Abattoirs effluent reaching rivers and streams may contribute significant levels of other nutrients, in addition to the levels of Biochemical

E. C. Ukpong, Department of Civil Engineering, Faculty of Engineering, University of Uyo, Akwa Ibom State, Nigeria 
Oxygen Demand (BOD), resulting in river pollution.

In Uyo capital city, various slaughter sites with inadequate facilities exist, slaughterhouses located at lba Oku often discharge blood and untreated wastewater into the environment. Fresh blood coagulates in drains, where it becomes putrefied, causing offensive odours as well as sanitary and environment problems. Edible and inedible by-products are frequently wasted during the process due to inefficient skills and discipline in slaughtering, poor equipments, low incentives for recouping by-products and lack of regulations and their enforcement constitute the core of the problem. Also these slaughterhouses do not maintain quality operations.

Agunwamba (2000) confirmed that the production of wastewater does not necessarily lead to environmental problems if the density of animal product processing is low enough to guarantee low concentration of pollutants in the receiving water bodies. Alonge (1991) gave more details concerning water conservation, as with slaughter, he attested that reduction of water use leads to a reduction in the total wastes load. Barrett (2001) stated that with inadequate slaughtering and disposal facilities, the abattoir has also become a source of infection and pollution, attracting domestic and wild carnivores, rodents and flies. The effect of the sanitation problems of abattoir in water quality was confirmed by Adeyemo (2002).

Sequel to the role of vetennary inspection in abattoir processes, Borda (2005) reported that, of the 39 slaughterhouses in Cluji country in Romania, recorded in 2002, the number decreased to 16 by the beginning of 2005 as the sanitary veterinary legislation became more restrictive. Adelegan (2002) argued that little interest has been shown in the contamination of groundwater by pollutants associated with slaughter wastes. The chemical composition of the groundwater approximately $250 \mathrm{~m}$ from the abattoir site was found unsatisfactory as raw water source for drinking purposes. The discoveries were shared by other resources like Akpan (2004). Abattoirs are frequently located near urban centers and enormous amounts of wastes are produced in relatively small areas. Meadows (1995) said that contamination can increase the level of nitrates in groundwater, which causes methaemoglobinmia or "blue baby syndrome".

\section{MATERIALS AND METHODS}

Data were collected on physicochemical, microbiological and elemental parameters of the slaughterhouse effluent, surface water and ground water samples. Sampling points of the surface water were selected to include: the control, the point where the discharged effluent meets and the stream, (upstream and downstream).

\section{$2.1 \quad$ METHOD OF DATA ANALYSIS}

\subsubsection{Analysis of physicochemical and elemental properties of water and slaughterhouses effluent \\ In order to ascertain the quality aspect of} water sources, water samples were collected in sterilized 2 litre plastic container with cover and labeled to show different samples and their respective sampling locations. Water samples were collected from the upstream and downstream and the surrounding boreholes at the slaughterhouses, as there are major sources of water for the butchers and the inhabitants of the surrounding communities. Measurements where made for the following parameters:

(i) Physical Parameters: $\mathrm{pH}$ level and temperature;

(ii) Chemical Parameters: Dissolved Oxygen (DO) content and Biochemical Oxygen Demand (BOD);

(iii) Nutrient Level: Nitrates-Nitrogen $\left(\mathrm{NO}_{3}-\mathrm{N}\right)$ and phosphates-phosphorus $\left(\mathrm{PO}_{4}-\mathrm{P}\right)$; and

(iv) Heavy Metals: Lead (Pb), Zinc (zn), Cadmium (Cd), Iron (Fe), Copper (Cu).

Standard methods were used to determine the above mentioned parameters as described by APHA (1995). All the values obtained were compared with WHO and FMENV/Housing and Urban Development Standards to see the extent to which the slaughterhouse effluent has impacted on the surface/ground water bodies.

\subsubsection{Analysis of bacteriological properties of water and slaughterhouse effluent}

The water samples collected were subjected to bacteriological analysis. Media preparation and culturing were carried out on the water samples for the following parameters: 
Total coliform MPN test, Total heterotrophic bacteria (HET), Escherichia Coli (E.Coli), Salmonella/Shigella, Vibirio and Feacal coliform.

\subsection{SAMPLING TECHNIQUE}

In order to carry out a detailed study on slaughterhouses, purposive sampling was applied to choose the two study sites: Iba Oku and Ntak Inyang slaughterhouses. These two slaughterhouses serve the entire populations of Uyo capital city. The sampling was done during the rainy season (September - October) and this greatly affected the values obtained for the different indicators.

\subsection{WATER SAMPLING}

\subsubsection{Physicochemical and microbial quality}

Samples for water quality were collected from each station (sampling point) directly by dipping the sampling container into the surface water. Separate samples were collected for the following analyses, using the 3 -litre plastic container that were pre-sterilized with hot water.

During sampling, sample bottles were rinsed with the sample to be analyzed several times and then filled to the brim. The samples were transported to the laboratory immediately and stored in the refrigerator at about $4^{\circ} \mathrm{C}$ prior to the analysis. In-situ measurements of ambient water temperature values were taken using mercury-in-glass broth thermometer. Values were taken in-situ on the collected samples using portable $\mathrm{pH}$ meter.

Water samples were collected from lba Oku and Etok stream situated few kilometers away from lba Oku and Ntak Inyang slaughterhouses, respectively. Four water samples were collected at equal distances apart. The first sample was taken before the suspected polluted site, therefore acting as a control, with the remaining three samples taken as follows: at the point where the effluent discharge meets the stream, upstream and downstream, respectively. The sites were chosen approximately 50 meters apart to allow dissiperation of any contamination influencing the subsequent site.

Site 1: This was the merging point of the effluent from the vicinity of the slaughterhouse dealing with cattle and the receiving stream. Slaughtering takes place between 7.00am and 10.00am. After slaughtering, the abattoir is washed with water containing a disinfectant and wastewater containing blood and feaces drains into the stream. There were no obvious other sources of contamination apart from wastewater from the slaughterhouses.

Site 2: This was located where the cattles are dragged to drink water from the stream. The washing of rumen contents also takes place around this zone.

Site 3: This is part of the stream where those living in and around the slaughterhouse environment fetch water for their domestic purposes. The inhabitants of the village even take their bath in the same steam.

Control:The first sample was taken before the suspected source, therefore acting as a control. The control coincidently serves both the lba Oku and Etok streams as both streams are tributaries from the Ikpa river located along the Calabar-Itu Highway.

The site locations (sites 1-3) and control are shown in Fig. 1. The Figure show the stream network of Ikpa river and 2 No. tributaries: Iba Oku stream and Etok stream respectively. In the same inter connected streams indicate control common to both streams as well as the up and down stream sampling points. 


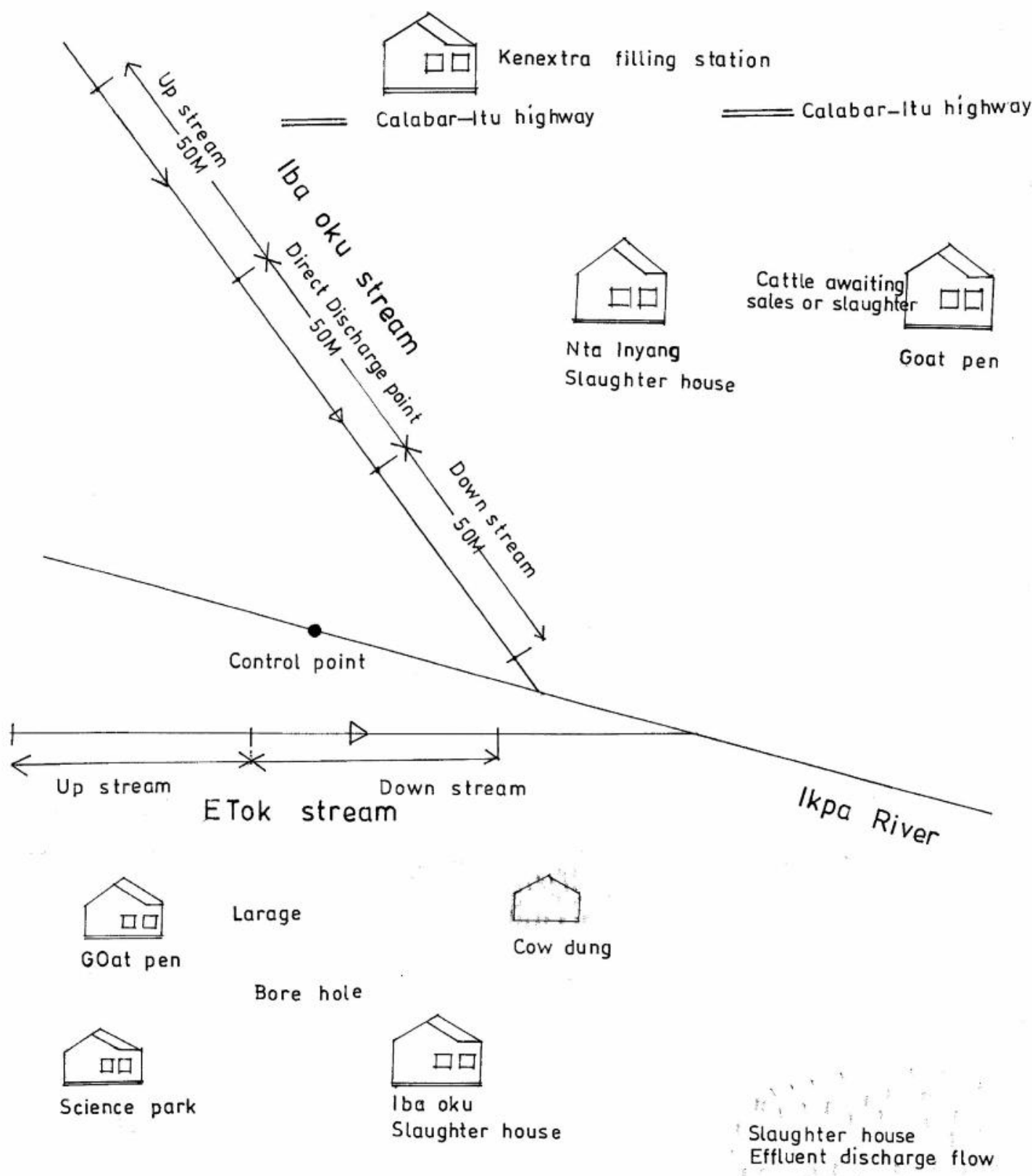

Figure 1: Network of $\mathrm{lkpa}$ River and two number tributaries: Iba oku stream and Etok stream showing slaughter houses and sampling points at the environment. 


\subsection{SEDIMENT SAMPLING}

Sediments are a veritable stratum for measuring the quality of aquatic ecosystems as the quality of sediment of a water body can be used to determine the presence and/or level of contaminants. The sediment was sampled for physicochemical microbiological and elemental characterization. At every sediment sampling point, composite sediment was taken by bulking 4 core samples collected within a 50 meters radius of each sampling point.

This was done to minimize sampling error and ensure that representative sediment samples were collected. The bulked core samples were normally thoroughly homogenized before sub-sampling for laboratory analysis. Depths of sediment sampling were $0.15 \mathrm{~cm}$ and $15-30 \mathrm{~cm}$. The samples were stored in a refrigerator in the laboratory while the analyses were carried out.

\subsection{SLAUGHTERHOUSE SAMPLING}

EFFLUENT

The effluent was sampled for physicochemical elemental and microbiological characterization. The effluent was collected using pre-sterilized 2 liter plastic container and covered immediately. The time of collection was appropriately 9.00am after slaughtering has taken place and the place washed up.

\section{DISCUSSION OF RESULT}

\section{Physicochemical parameters in streams}

Table 1 shows some physicochemcial properties of surface water samples from Ntak Inyang slaughterhouse environment. The results presented in Tables 1 and 2 have revealed that the surface water $\mathrm{pH}$ values exhibited narrow margin of variation (5.10-7.20). The acidic nature is due to the presence of urea and the cow dung deposit in its concentrated form. Nevertheless, these values are lower by 3.0 than the WHO recommended upper limit of 8.50 . The $\mathrm{pH}$ value is a measure of the acidity if value is below 7 or alkalinity and where values is above $7 . \mathrm{pH}$ values in the different sampling points from lba Oku stream and Etok stream varies between 5.10 and 7.20. It was observed that the Ntak Inyang slaughterhouse environment has acidic tendency which shows the unhygienic disposal of cow dung in and around the slaughterhouse environment being washed down into the stream was responsible.

Dissolved oxygen in water samples from both streams (lba Oku and Etok) ranged between 0.21 and $4.12 \mathrm{mg} / \mathrm{l}$ indicating relatively low oxygenation. The low dissolve oxygen levels in site 1 for both slaughterhouses during the wet season that the analysis was carried out is attributed to the excess slaughterhouse washing load. The values were lower by $4.79 \mathrm{mg} / \mathrm{l}$ and higher by $3 \mathrm{mg} / \mathrm{l}$ compared to the WHO (1984) limit of $5.0 \mathrm{mg} / \mathrm{l}$ needed to support fish and invertebrates in water. As such their death renders the water unfit for human consumption. Interestingly, site - 2 recorded a high values of DO dilution and self purification of the stream which could be responsible for this marked difference.

Table 1: Physico-chemical properties of surface water samples from Ntak Inyang slaughterhouse environment

\begin{tabular}{|c|c|c|c|c|c|c|c|}
\hline \multirow[t]{2}{*}{$\mathbf{S} / \mathbf{N}$} & \multirow[t]{2}{*}{ PARAMETERS } & \multicolumn{4}{|c|}{ SAMPLING POINTS } & \multirow[t]{2}{*}{ WHO LIMIT } & \multirow{2}{*}{$\begin{array}{l}\text { FMENV } \\
\text { LIMIT }\end{array}$} \\
\hline & & 土ST1 & ST2 & ST3 & CONTROL & & \\
\hline 1 & Temperature $\left({ }^{\circ} \mathrm{C}\right)$ & 26.30 & 28.2 & 27.10 & 26.20 & 25 & 35 \\
\hline 2 & $\mathrm{pH}$ & 5.10 & 7.10 & 6.10 & 5.50 & 8.50 & 6.50 \\
\hline 3 & $\mathrm{DO}(\mathrm{mg} / \mathrm{l})$ & 0.21 & 6.80 & 3.51 & 0.23 & 5.0 & - \\
\hline 4 & $\mathrm{BOD}(\mathrm{mg} / \mathrm{l})$ & 4.11 & 0.10 & 2.4 & 3.98 & 1.0 & - \\
\hline 5 & $\mathrm{NO}_{3}^{-}(\mathrm{mg} / \mathrm{l})$ & 0.40 & 0.01 & 0.21 & 0.80 & $10.00-50.00$ & - \\
\hline 6 & $\mathrm{PO}_{4}^{3-}(\mathrm{mg} / \mathrm{l})$ & 0.126 & $\mathrm{ND}^{*}$ & 0.112 & 0.094 & 5.00 & 5.00 \\
\hline
\end{tabular}

Source: Author's Field Work (2006)

${ }^{*} \mathrm{ND}=$ Not Detected; \pm ST1 = Site $-1, \mathrm{ST} 2=$ Site $-2, \mathrm{ST} 3=$ Site -3 
The Biochemical Oxygen Demand (BOD) was generally higher at most sampling points in both streams, including the control station, compared to $1.0 \mathrm{mg} / \mathrm{l}$ limit recommended by WHO (1984). What accounted for these high BOD values was the main polluting component of the slaughterhouse washings, the blood, fats, oil, punch manure and intestinal content.

The nutrients: nitrate $\left(\mathrm{NO}_{3}-\mathrm{N}\right)$ and phosphate $\left(\mathrm{PO}_{4}-\mathrm{P}\right)$ varied remarkably in the streams. The low value of phosphate was surprising as there was a prolific algal growth in the Etok stream. This is unfortunate as the bluegreen algae could release toxic cyanotoxina into the receiving water causing death of farm livestock. The likelihood of algae growth would cause eutrophication. From the Table 2, levels of nitrate in the receiving stream slightly decreased downstream from the point of receiving effluent. This can be explained through the process of self purification and the period of rainy season the samples were taken.

Table 2: Physico-chemical properties of surface water samples from lba Oku slaughterhouse environment

\begin{tabular}{|l|l|l|l|l|l|l|l|}
\hline \multirow{2}{*}{ S/N } & Parameters & \multicolumn{4}{|l|}{ SAMPLING POINTS } & \multirow{2}{*}{ WHO Limit } & \multirow{2}{*}{$\begin{array}{l}\text { FMENV } \\
\text { Limit }\end{array}$} \\
\cline { 3 - 6 } & & $\mathbf{\pm S T 1}$ & $\mathbf{S T 2}$ & $\mathbf{S T 3}$ & Control & & \\
\hline 1 & Temperature $\left({ }^{\circ} \mathrm{C}\right)$ & 27.10 & 28.50 & 27.80 & 26.20 & 25 & 35 \\
\hline 2 & $\mathrm{pH}$ & 5.82 & 7.40 & 6.61 & 5.50 & 8.50 & 6.50 \\
\hline 3 & $\mathrm{DO}(\mathrm{mg} / \mathrm{l})$ & 0.24 & 8.00 & 4.12 & 0.23 & 5.0 & - \\
\hline 4 & $\mathrm{BOD}(\mathrm{mg} / \mathrm{l})$ & 4.21 & 0.20 & 2.21 & 3.98 & 1.0 & - \\
\hline 5 & $\mathrm{NO}_{3}^{-}(\mathrm{mg} / \mathrm{l})$ & 0.061 & 0.02 & 0.04 & 0.80 & $10.00-50.00$ & - \\
\hline 6 & $\mathrm{PO}_{4}^{3-}(\mathrm{mg} / \mathrm{l})$ & 0.151 & $\mathrm{ND}$ & 0.112 & 0.084 & 5.00 & 5.00 \\
\hline
\end{tabular}

Source: Author's Field Work (2006)

\section{Heavy metals in sediment}

The heavy metals concentration in sediment samples from Iba Oku and Ntak Inyang slaughterhouse environment are shown in Table
3. They showed remarkably high values. This is accounted for by the low $\mathrm{pH}$ which increases the solubility of many of these metals such as Fe, Cd (Morrison, 2001).

Table 3: Heavy metals concentration in the sediment samples from the slaughterhouse environment

\begin{tabular}{|l|l|l|l|l|l|}
\hline Samples & $\mathrm{Cd}(\mathrm{mg} / \mathrm{l})$ & $\mathrm{Fe}(\mathrm{mg} / \mathrm{l})$ & $\mathrm{Pb}(\mathrm{mg} / \mathrm{l})$ & $\mathrm{Cu}(\mathrm{mg} / \mathrm{l})$ & $\mathrm{Zn}(\mathrm{mg} / \mathrm{l})$ \\
\hline $\begin{array}{l}\text { Sediments from } \\
\text { Ntak Inyang }\end{array}$ & 0.15 & 10.05 & 21.55 & 30.2 & 0.30 \\
\hline $\begin{array}{l}\text { Sediment from Iba } \\
\text { Oku }\end{array}$ & 20.24 & 138.9 & 23.21 & 1264 & 64.66 \\
\hline Control & 0.10 & 21.40 & 52.65 & 16.05 & 0.15 \\
\hline WHO Limit & 0.003 & 3.00 & 0.5 & 1.11 & 0.01 \\
\hline
\end{tabular}

Source: Author's Fieldwork (2006)

From Table 3, the values of cadmium $(\mathrm{Cd})$ and lead $(\mathrm{Pb})$ in sediment from Ntak Inyang slaughterhouse environment $0.15 \mathrm{mg} / \mathrm{l}$ and $21.55 \mathrm{mg} / \mathrm{l}$ and $20.24 \mathrm{mg} / \mathrm{l}, 23.21 \mathrm{mg} / \mathrm{l}$ were much higher than the WHO limit of $0.003 \mathrm{mg} / \mathrm{l}$ and $0.5 \mathrm{mg} / \mathrm{l}$, respectively. Some higher values for both cadmium and lead were recorded at the control stations as noted for the heavy metals concentrations in the surface water samples; what could be responsible for this is the refuse dump situated kilometers away from the stream.

Iron (Fe) was found to be particularly in high amount $(138.9 \mathrm{mg} / \mathrm{l})$ especially at the Iba Oku, slaughterhouse environment. Also, Copper (Cu) recorded high values of $21.55 \mathrm{mg} / \mathrm{l}$, $126.4 \mathrm{mg} / \mathrm{l}, 23.21 \mathrm{mg} / \mathrm{l}, 52.65 \mathrm{mg} / \mathrm{l}$ and $16.05 \mathrm{mg} / \mathrm{l}$ in 
the sediment from Ntak Inyang, Iba Oku control environment.

Lead $(\mathrm{Pb})$ poisoning is rare, but relatively low levels of chronic exposure as expected in areas investigated in this study can produce adverse health effects, that may interfere in the red blood cell chemistry, delays in normal physical and metal development in babies and young children, slight deficits in the attentions span, hearing and learning abilities of children, and slight increase in blood pressure of some adults.

Possible sources of the metal contaminants of the element is likely to be concentrates of the feeds present in the rumen which is washed down as effluent into the environment. Also chronic exposure of cadmium (Cd) in animals and human results in kidney dysfunction, anemia and liver damage (Klaassen, 2001). Although iron (Fe) is an essential dietary elements, ingestion of large quantities has been shown to result in haemochromatisis.

\section{Physico-chemical parameters in sediments}

Table 4 gives summary values of some physico-chemical properties of sediment samples from both the Ntak Inyang and Iba Oku slaughterhouse environments. A composite sample was formed from collecting samples from the sampling points and taking $1.0 \mathrm{~g}$ of each of them to form a bulk.

Table 4: Physico-chemical properties of sediment samples from Ntak Inyang and Iba Oku environment

\begin{tabular}{|l|l|l|l|}
\hline Parameters & $\begin{array}{l}\text { Ntak Inyang } \\
\text { slaughterhouse } \\
\text { Sediment }\end{array}$ & $\begin{array}{l}\text { Iba Oku Claughterhouse } \\
\text { Slantrol }\end{array}$ & C \\
\hline $\mathrm{pH}$ & 5.40 & 5.62 & 6.20 \\
\hline $\mathrm{EC} \mathrm{(ds/m)}$ & 1.369 & 1.45 & 0.22 \\
\hline Organic Matter (\%) & 2.74 & 2.66 & 2.58 \\
\hline $\begin{array}{l}\text { Available phosphorus } \\
(\mathrm{mg} / \mathrm{kg})\end{array}$ & 8.46 & 7.46 & 1.47 \\
\hline
\end{tabular}

Source: Author's Fieldwork (2006)

From Table 4 it is evident that the $\mathrm{pH}$ for sediments from Ntak Inyang slaughterhouse environment tends to be acidic with a value of 5.40. This is lower than that at the Iba Oku and control station with values of 5.62 and 6.20 , respectively. The organic matter and percentages of $2.74,2.66$ and 2.58 at the Ntak Inyang, lba Oku and control station, respectively. The values for available phosphorus were slightly higher than those for total nitrogen. The available phosphorus values for the Ntak Inyang and Iba Oku sediment samples were comparatively high, having $8.46 \%$ and $7.4 \%$, respectively. This was a sharp distinction from the values of available phosphorus recorded for the control station with $1.47 \%$. The total nitrogen percentage ranged from 0.05-0.07 for the Ntak Inyang control and Iba Oku slaughterhouse environment.

\section{Microbial populations in surface water}

Tables $5 a$ \& $b$ summarized the results of the microbial counts for the water collected from stations within the study area. In the water samples, the heterotrophic bacteria (HET) count for the 3 sampling station ranged from $3.7 \times 10^{5}$. $6.1 \times 10^{7} \mathrm{cfu} / \mathrm{ml}$. The total coliform count (TCC) of the water samples ranged from $3.2 \times 10^{3}$ $6.3 \times 10^{5} \mathrm{cfu} / \mathrm{ml}$. While the fungal count ranged between $3.4 \times 10^{2}$ and $8.0 \times 10^{4} \mathrm{cfu} / \mathrm{ml}$ and the salmonella/shigella varied between $1.6 \times 10^{4}$ to $6.3 \times 10^{3} \mathrm{cfu} / \mathrm{ml}$. Vibirio ranged from $2.7 \times 10^{3}$ to $7.1 \times 10^{2} \mathrm{cfu} / \mathrm{ml}$. 
Table 5a: Microbial populations in water (cfu/ml) samples from lba Oku surface water

\begin{tabular}{|l|l|l|l|l|}
\hline \multirow{2}{*}{ Parameter } & \multicolumn{4}{|l|}{ Sampling Stations } \\
\cline { 2 - 5 } & Control & $\mathbf{S T}_{\mathbf{1}}$ & $\mathbf{S T}_{\mathbf{2}}$ & $\mathbf{S T}_{\mathbf{3}}$ \\
\hline HET (cfu/ml) & $3.7 \times 10^{5}$ & $5.5 \times 10^{7}$ & $6.1 \times 10^{7}$ & $4.1 \times 10^{7}$ \\
\hline Total Coliform Bacteria (cfu/ml) & $3.8 \times 10^{3}$ & $4.2 \times 10^{6}$ & $3.7 \times 10^{4}$ & $5.2 \times 10^{6}$ \\
\hline Salmonella/Shigella (cfu/ml) & $1.7 \times 10^{2}$ & $4.1 \times 10^{3}$ & $2.7 \times 10^{3}$ & $1.6 \times 10^{3}$ \\
\hline Vibirio (cfu/ml) & $5.2 \times 10^{2}$ & $3.1 \times 10^{3}$ & $2.7 \times 10^{3}$ & $1.6 \times 10^{3}$ \\
\hline Fungal Count (cfu/ml) & $3.6 \times 10^{3}$ & $4.3 \times 10^{4}$ & $3.6 \times 10^{4}$ & $5.2 \times 10^{4}$ \\
\hline
\end{tabular}

Source: Author's Fieldwork (2006); HET = Total Heterotrophic Bacteria

Table 5b: Microbial populations in water (cfu/ml) samples from Ntak Inyang surface water

\begin{tabular}{|l|l|l|l|l|l|}
\hline & $\begin{array}{l}\text { Sampling } \\
\text { Points }\end{array}$ & & & & \\
\hline Parameter & Control & ST1 & ST2 & ST3 & Mean \\
\hline HET (cfu/ml) & $4.1 \times 10^{4}$ & $3.5 \times 10^{6}$ & $4.6 \times 10^{6}$ & $3.6 \times 10^{6}$ & $2.9 \times 10^{6}$ \\
\hline $\begin{array}{l}\text { Total Coliform } \\
\text { Bacteria (cfu/ml) }\end{array}$ & $3.2 \times 10^{3}$ & $3.2 \times 10^{5}$ & $5.2 \times 10^{5}$ & $6.3 \times 10^{5}$ & $3.8 \times 10^{5}$ \\
\hline $\begin{array}{l}\text { Salmonella/Shigella } \\
\text { (cfu/ml) }\end{array}$ & $2.1 \times 10^{2}$ & $3.2 \times 10^{2}$ & $7.1 \times 10^{2}$ & $4.2 \times 10^{2}$ & $4.6 \times 10^{6}$ \\
\hline Vibirio (cfu/ml) & $4.1 \times 10^{2}$ & $3.1 \times 10^{2}$ & $7.1 \times 10^{2}$ & $4.2 \times 10^{2}$ & $4.6 \times 10^{6}$ \\
\hline $\begin{array}{l}\text { Fungal Count } \\
\text { (cfu/ml) }\end{array}$ & $3.4 \times 10^{2}$ & $4.2 \times 10^{2}$ & $3.7 \times 10^{4}$ & $8.0 \times 10^{4}$ & $3.9 \times 10^{4}$ \\
\hline
\end{tabular}

Source: Author's Fieldwork (2006)

In general, the concentration of the physico-chemical parameters were low and did not indicate serious environmental degradation (water pollution) and were slightly below the ranges allowed by the regulatory agencies (WHO and FMEnv).

\section{Micro-organism isolated from slaughterhouse effluent}

Table 6 presents the distribution of the common microbial genera encountered in the environment. Bacillus, Escherichia coli and Micrococcus were the most widely distributed bacteria isolates, while Enterococcus, Staphylococcus species indicates the risk of human infections.

Table 6: Micro-Organisms Isolated from Iba Oku and Ntak Inyang Slaughterhouse Effluent

\begin{tabular}{|l|l|l|l|}
\hline $\mathbf{S} / \mathbf{N}$ & Bacteria & $\begin{array}{l}\text { Iba Oku } \\
\text { Slaughterhouse } \\
\text { Effluent }\end{array}$ & $\begin{array}{l}\text { Ntak Inyang Slaughterhouse } \\
\text { Effluent }\end{array}$ \\
\hline 1 & Escherichia coli & + & + \\
\hline 2 & Staphylococcus aerus & + & + \\
\hline 3 & Enterococcus & + & + \\
\hline
\end{tabular}

Source: Author's Fieldwork (2006)

(+ = Gram positive indicates their presence)

Microbial population in slaughterhouse effluent

Table 7 reveals the microbial populations in the effluents samples. These were slightly higher than the values obtained from the water samples. The heterotrophic bacterial count was relatively high and unstable. On the other hand, the density of Coliform bacteria was more stable 
having a mean value of $3.8 \times 10^{5} \mathrm{cfu} / \mathrm{ml}$. This is an indication that the streams investigated are under persistent contamination by human and animal faeces and that faecal matter is a chronic pollutant in the aquatic environment surrounding the study area therefore, their usefulness as indices of pollution in the said environment may be misleading.

Table 7: Microbial Populations in Effluent (cfu/ml) Samples from Slaughterhouse

\begin{tabular}{|l|l|l|}
\hline Parameter & Ntak Inyang & Iba Oku \\
\hline HET $(\mathrm{cfu} / \mathrm{ml})$ & $7.2 \times 10^{8}$ & $6.8 \times 10^{8}$ \\
\hline Total Coliform Bacteria $(\mathrm{cfu} / \mathrm{ml})$ & $6.6 \times 10^{7}$ & $7.2 \times 10^{6}$ \\
\hline Salmonella/Shigella $(\mathrm{cfu} / \mathrm{ml})$ & $7.3 \times 10^{3}$ & $3.1 \times 10^{3}$ \\
\hline Vibirio $(\mathrm{cfu} / \mathrm{ml})$ & $3.1 \times 10^{4}$ & $2.1 \times 10^{4}$ \\
\hline Fungal Count $(\mathrm{cfu} / \mathrm{ml})$ & $7.3 \times 10^{4}$ & $6.1 \times 10^{5}$ \\
\hline
\end{tabular}

Source: Author's Fieldwork (2006)

The high incidence of HET, TCC and Fungi count in the water and effluent samples is an indication of the high nutrient status of the substrates. Their variability is a pointer to their potential as indicators of microbial response to environmental impact in the project environment. coliform bacteria are enteric bacteria that are used as indicators of the likelihood of the presence of bacterial pathogens. Although faecal coliforms themselves are usually not harmful to humans, their presence indicates the presence of faecal wastes, which may contain pathogens.

\section{CONCLUSION}

Water, already scarce in many parts of the world, can be greatly affected by livestock production. Water is required not only for animals' drinking, human domestic use but to grow feed crops and for waste disposal. Pollution of land and water is another concern as is the impact by livestocks, directly or indirectly on biodiversity. Greenhouse gases, of which about 5-10 percent is produced by livestock waste contribute to global warming. The interaction between livestock and the environment cannot be ignored but mythical misconceptions must be overturned in favour of reality. Livestock do not destroy the environment, people do. Ignorance, indifferent and policies which misguide resources use are responsible for environmental degradation.

Hence, pollution prevention measure suggested for slaughterhouse in Uyo is a product recovery and waste minimization strategy. This study provides example where livestock and environment interaction are particularly critical, that is, environmental "hotspots".

Finally, there is an urgent need to strengthen pollution control and enforcement mechanism and to establish financial independence of slaughterhouses in Uyo Capital City, Akwa Ibom State which now, frequently, see all their income going back to the public coffers, without re-investment in maintenance and infrastructure improvements.

Meat processors must operate in a manner that protects human health and the environment while maintaining the highest food safety standards. If slaughterhouse wastes are not minimized and properly managed, these operations can create enormous negative impacts on the environment. The primary environmental issues associated with meat processing are water use, high strength effluent discharge, and energy consumption.

\section{REFERENCES}

Adelegan, J. A., 2002. Environmental Policy and Slaughterhouse Waste in Nigeria: Sustainable Environmental Sanitation and Water Services, Proceedings of the $28^{\text {th }}$ Eedc Conference, Kalkata, India.

Adeyemo, O. K., 2002. "Unhygienic Operation of a City Abattoir in South Western Nigeria". Environmental Implication, African Journal of Environmental Assessment and Management. 4, (1):

Agbogu, V. N., Umoh, V. J., Okuofu, C. A., Smith, 
S. I and Ameh, J. B., 2005. "Study of the Bacteriological and Physioch emical Indicators of Pollution of Surface Waters in Zaria, Nigeria" African Journal of Biotechnology 5, (9): $732-737$.

Agunwamba, J. C., 2000. Water Engineering System. Immaculate Publications Limited, No 2 Aku Street, Ogui New Layout, Enugu, Enugu State, Nigeria. 92 $-118$.

Akpan, A. W., 2004. "The Water Quality of Some Tropical Freshwater Bodies in Uyo (Nigeria) Receiving Municipal Effluent, Slaughterhouse Washings and Agricultural Land Drainage". The Environmentalist. 24, $49-51$.

Alonge, D. O., 1991. Textbook of Meat Hygienic in the Tropics. Farmcoe Press lbadan, Nigeria. 50.

Amoah, P., Keraia, B and Drechsel, P., 2003. "Influence of Urban Wastewater on Stream Water Quality and Agriculture" In and Around Kumasi, Ghana: Urban Wastewater Agriculture. The Environmental and Urbanization. 15, (2): 171-178. (Available at wwwidic.Ca/En/Ev-68337-201-1-Do_Topi c.Html. Accessed January30,2007).

Barnett, H. L and Hunters, B. B., 1987. Illustrated Genera of Imperfect Fungi. $4^{\text {th }}$ Edition Burgress pub. Company USA.

Barret, J. R., 2001. "Livestock Farming Eating up the Environment?" Environmental Health Perspective. 109(7), A312-A317.

Bates, P and Philips, C. A., 2005. "Agricultural Practice as a Source of Campylobacter Spp. In River Water". Journal of Environmental Health Research. 4, (1): $19-25$.

Bellows, A., Robinson, V., Guthrie, J., Meyer, T., Peric, T and Hamm, M. W., 2000. "Urban Livestock Agriculture in State of New Jersey". In: Urban Agriculture Magazine, No. 2 Urban Livestock, October 2000 RUAF, Leusden the Netherlands. (available at http://www.ruaf.org/node/12 0).(accessed October 20, 2006).

Ben-Coker, M. O and Ojior, O. O., 1995. "Effect of Slaughterhouse Wastes on the Water Quality of Ikpoba River, Nigeria" BioResource Technology, 52, pp. 5- 12.

Blaha, T., 2005. Animal health, animals welfare, pre-havest food safety and Warsaw, Poland. 1, $17-21$.

Borda, C and Draghici, C., 2004. Double Setting Efficiency of Slaughterhouse Wastewater. In: Processing of the 11th International Conference of FAO ESCORENA Network on Recycling of Agriculture, Municipal and Industrial Residues in Agriculture (RAMIRAN), Murcia, Spain. $250-252$.

Borda, C., Draghici, C and Popescu, S., 2003. Primary Treatment Efficiency of Wastewater from Slaughterhouse, In: Processing of the 4th International Conference of Ph.D Students.Miskole, Hungary. $191-193$.

Ezeronye, O. U and Ubalua, A. O., 2004. "Studies on the Effect of Abattoir and Industrial Effluents on the Heavy Metals and Microbial Quality of Aba River in Nigeria" African Journal of Biotechnology. 4, (3): $266-272$.

Fried, J. J., 1991. "Nitrates and their Control the EEC Aquatic Environment". In: Borgodi, L. and Kuselka, D. (Eds). Nitrate Contamination, Exposure Consequences and Control. NATO ASI Series G30, Ecological Sciences Springer-Verlag. Berline, 55 - 63.

Ghirotti, E., 1996. International Book on Environmentally Sound Technologies for Municipal Solid Waste Management. Appendix 1, UNEP. Osaka, Japan.

Ghirotti, M., 1999. Making Better Use of Animal Resources in a Rapidly Urbanizing World: A Professional Challenge. World Annual Review 92, 2 - 14. 
Hardoy, J. E and Satterthwaite, D., 1997. Environmental Problems in Third World Cities. London, Earthscan.

Hoddinott, J., 1997. Water, Health and Income: A Review, FCND/IFPRI Discussion Paper 2, February Edition.

Holland, W. W., 1972. Air Pollution and Respiratory Disease. Technomic, Westport Connection. 258.

Lvovsky, K., 2001. Health and Environment Strategy Papers, No.1 the International Bank for Reconstruction and Development/the World Bank, Washington D.C pp. 37. Available at http://www.who.int/watersanitationhealth/ watandmacr6.pdf). (Accessed November 20, 2006).

Meadows, R., 1995. "Livestock legacy" Environmental Health Perspectives 103(12) pp. 1096; 1100.

Mitchell, R and Chet, I., 1978. "Indirect Ecological Effects of Pollution" In: R. Mitchell (ed). In Water Pollution Microbiology, John Wiley and Sons, New York (2): 177 199. 